\title{
Gender and Power in Selected Works of Chinua Achebe an Chimamanda Adichie: An Analytic Reappraisal
}

\author{
Musibau O. LAWAL (Ph.D) \\ Department of English and International Studies, College of Humanities and Culture, Osun \\ State University (Ikire Campus)Osogbo, Nigeria \\ musibau.lawal@uniosun.edu.ng
}

DOI: http://doi.org/10.36892/ijlls.v2i2.319

\begin{tabular}{|c|c|}
\hline Received: & Abstract \\
\hline 25/03/2020 & Indeed, gender and power discourses as ideological concessions have been \\
\hline $\begin{array}{l}\text { Accepted: } \\
25 / 05 / 2020\end{array}$ & $\begin{array}{l}\text { investigated and reviewed from various perspectives by different scholars in the } \\
\text { works of Chinua Achebe and Chimamanda Adichie. This paper offers a } \\
\text { reappraisal of the views of the scholars essentially on the issues of gender and } \\
\text { power in the selected works of Achebe and Adichie, viz: Achebe's Anthills of }\end{array}$ \\
\hline $\begin{array}{l}\text { Keywords: } \\
\text { Gender, Power, Chinua } \\
\text { Achebe, Chimamanda } \\
\text { Adichie, Reappraisal }\end{array}$ & $\begin{array}{l}\text { the Savannah and There Was a Country and Adichie's Purple Hibiscus and Half } \\
\text { of a Yellow Sun. The work, therefore, gives a reappraisal of the thoughts of } \\
\text { scholars and presents a coalescence of their views, offering a distillation and } \\
\text { filtration of the ideas they proffer on the selected works and projecting a } \\
\text { comparatively valid arbitration and settlement where the views of the scholars } \\
\text { are going inordinately radical and amorphous. } \\
\text { The paper views that the opinion of the scholars on the discourses of } \\
\text { gender and power specifically on the selected works of Achebe and Adichie are } \\
\text { incongruous and asymmetrical while some of the views are inordinately on the } \\
\text { verge of radicalism. This work, however, proffers a comparatively balanced } \\
\text { perspective on the diverse views of the scholars with a view to navigating an } \\
\text { even horizon. . }\end{array}$ \\
\hline
\end{tabular}

\section{INTRODUCTION}

Gender and power are prominent thematic preoccupations in Chinua Achebe's and Chimamanda Adichie's literary works. A considerable number of scholars such as: Azuike (2009), Anyokwu (2011), Ekhator (2014), and Bernard and Kinggeorge (2014) among others have proffered variegated views on the thematic concern and the intents of the two writers especially in Achebe's Anthills of the Savannah and There Was a Country and Adichie's Purple Hibiscus and Half of a Yellow Sun with specificity on the issues of gender and power, but some of the views of the scholars fall sort of what the writers might have portended in the works, while some exhibit a rather radical ideological concessions of the scholars. For instance, where Adichie, in the selected works, is not portraying or preaching an outright radicalism in her feminist ideology, some of the scholars, in their reviews, present her to be doing so; which is highly in contradistinction with what the author seems to exhibit in her feminine ideological belief. Again, where Achebe, as against his earlier novels like Things Fall Apart, softens his harsh criticism and subjugation of the women folk, some of the scholars represent him as an unrepentant masculinist.

The point now is that while some of the scholars are providing instances of Chinua Achebe being an unrelented masculinist and the radical femisnists amongst them are preaching equality between the male and the female and are also putting forward argument for male subjugating the female gender in Adichie's works, none of them has really proved that it is the women that, most of the time, actually rule the men. As it is fervently argued by 
Chinweizu (1990) which I glossed in my (2019) Ph.D Thesis, and summarised as follows that it is the women that, often times, rule the men and not the other way round. "A man is argued to be ruled from his cradle to his grave by the woman. He is ruled by the woman by craving for the products of her womb; he is ruled in his cradle by his mother by molding him to what she wants him to be built into (mother power); he is ruled by his bride (bride power) who later becomes his wife; his kitchen is annexed by his wife and his stomach is controlled through it; and ' man's psychological immaturity and his deranging penis are evolution's special handicaps on him through which his woman rules him' (p.16). ',

This paper, therefore, examines the views of the learned people and offers a somewhat, balanced opinion of what the intents of the writers, Achebe and Adichie, have more or less portended on the discourses of gender and power in the mentioned works.

\section{OBJECTIVES}

The major objective of this work is to examine the various views of scholars on the discourses of gender and power, weigh the pros and cons of their ideas and proffer a comparatively even assessment of the scholars' opinion

\section{METHODOLOGY}

This work makes a coalescence of opinion and views of scholars on the issues of gender and power of some selected works of Chinua Achebe and Chimamanda Adichie, sieving the ideas of the scholars and offering an even appraisal of the writers' thematic preoccupations.

\section{ANALYSIS}

Chinua Achebe's works Anthills of the Savannah and There Was a Country, and those of Chimamanda Adichie: Purple Hibiscus and Half of a Yellow Sun have been widely read and critically analysed by both literary and linguistic scholars. Bamiro (2006:315) looks into the intersection strategies: Nigerianisms at the intersection of ideology and gender in Achebe's fiction Anthill of the Savannah. He observes that 'Achebe has always emphasised the geolinguistic credo of fashioning a New English in the African context' He comments generously on Achebe's linguistic word choice and his sexist bias against the women folk. Stressing further, he opines that Achebe, in his geolinguistic credo, has dabbled in various bids by his use of linguistic devices to contextualise the English language in his Igbo culture. Bamiro expressly quotes Achebe in his defence for his nativisation of the English language, as Achebe projects:

Is it right that a man (sic) should abandon his (sic) mother tongue for someone else's? lt looks like a dreadful betrayal and produces a guilty feeling. But for me there is no choice. I have been given the language (i.e English) and I intend to use it. I feel the English language will be able to carry the weight of my African experience (1975:62).

In the same vein, Igboanusi (2000) in an attempt to establish the ethnic distinctiveness and variety of Igbo English and stylistic devices in Anthills of the Savannah, demonstrates that Igbo English is an intentional and deliberate stylistic word choice arising from the influence of the Igbo culture and language on English, giving instances of the novels of Cyprian Ekwensi, Buchi Emecheta and Chinua Achebe among other ones. Nevertheless, a lot of those analyses have focused on the pedestal of 'relexification' which is directed towards showing how Achebe relexifies his mother tongue ' using English vocabulary but indigenous (Igbo) structures and rhythms"' (Todd 1982:297-8).

Alluding to this, Zabus (1990:19) observes that Achebe, altogether, puts the English language to a system or process of adaptation to meet his native cultural ideological experience by marrying into many speech forms dialogues and narration translated from his Igbo language. By implication, Zabus is mainly interested in how Achebe is able to use or capture in the 
English language, the metaphor, idiom and mundane language and convection so archetypal of the Igbo people.

Furthermore, Bamiro (2006:315) identifies a multilingual (Igbo, Hausa. Yoruba) code mixing experience in Anthills of the Savannah which is a representation of the linguistic interaction of the native languages in post-colonial Nigeria against the bilingual (Igbo with English only) code-mixing experience of what is realized in Things Fall Apart. It is evident here that Bamiro (2006), Igboanusi (2000) and Zabus (1990) try to demonstrate Achebe's feat in his attempt to use the English language creatively to encapsulate the Igbo language and their socio-cultural realities; this study is different from their claims or rather it takes a step further in that the study looks at the motivational factors behind Achebe's use of language with specific attention to gender and power ideological preoccupations. Again, Proyect (2003:3) observes that Achebe in an attempt to show the blatant failure of social justice and democracy taking root in post-colonial Nigeria dramatises and satirises the impasse in the 1987 Anthills of the Savannah. Proyect posits further that some of the characters, as aroused but rather impotent elite figures, obviously were satirically chosen by Achebe to reflect his own frustrations with Nigeria and mixed feelings about the future of Africa. He states, in addition, that those looking for heroic victories over oppression must look elsewhere than in Achebe's comparatively deeply complex and multilevelled work; those looking for a stirring message about revolutionary struggles will not find any such thing in Anthills of the Savannah. It is imbued with a very deep mood of futility that is only broken by the personal examples of self-sacrifice by the major characters. Much as Proyect's position is valid, it fails to look at Achebe's characterisation in Anthills of the Savannah and the characters' bid to abuse power and dominate one another and Achebe's use of language to exhibit this social reality.

In another study, Ojaide (1989) discusses the concept of communality in traditional African society in Anthills of the Savannah and as co-contextual participants, he uses Soyinka's The Interpreters and Ngugi's Petals of Blood. In addition, Lukacs (1990) examines the affair of intellectual physiognomy in creating living personality in literature in Africa with somewhat nostalgic and bias reference to personalities such as Ikem Osodi in Anthills of the Savannah.

Onyemelukwe (2011) undertakes a critical discourse analysis of ideology and meaning in three novels of Chinua Achebe: Things Fall Apart, A Man of the People and Anthills of the Savannah. In the study, he critically investigates the ideological and underlying meanings expressed in the novels and identifies the prominent linguistic and rhetorical features deployed to express them. Onyemelukwe, in the work, attempts to show that the linguistic and rhetorical features identified and explained in the novels are effectively deployed, and as a follow-up, he identifies the topical socio-political, pedagogical and discourse implications in the novels. As Ojaide conceptualises African communality in Achebe's Anthills of the Savannah and other African literature and Onyemelukwe looks at ideology and meaning in some Achebe's selected works, the reasons behind the author's gender and power ideological expressions were not addressed. This study therefore pays attention to this lacuna. Balogun (2010) investigates the clause as a representation of power and gender in selected works of Akachi Adimora-Ezeigbo; the clause as a major grammatical rank scale is used by her to explore the theme of power and gender in her study. This study is, however, different from others for the fact that the motivational factors for the use of language in relation to the ideological configurations of gender and power of selected works of Achebe and Adichie were explored.

In a study carried out by Anyokwu (2009:106) on Chimamanda Adichie's magnum opus, Purple Hibiscus, the concept of postmodern gothicism is generally addressed. As he explains, Purple Hibiscus being a rare fragrant flower and a product of horticultural alchemy, carries an undertone of freedom, "a different kind of freedom". He maintained further that the theme portents an ideological zest for freedom. The use of language and the style of Adichie's writing portray an undertone of a movement from a state of imprisonment to that of victory and freedom. The horticultural signifier in Anyokwu's expression speaks to the 
central symbolism and leitmotif of the narrator's name. In the overall, Anyokwu investigates the postmodern gothic issue of Purple Hibiscus stressing the irrational and perverse inclinations of Eugene, dodging or hiding under the cover of his civilised mind.

In addition, Olomo (2011:5) discusses generously the validity of Purple Hibiscus in the Nigerian contemporary society and he came to the conclusion that the novel is a good instance of a nice wine brewed at the very first time of refining. Hope (2004:4) examines the horror perspective of Purple Hibiscus. In his book review which he titled: "Love in a time of terror", he comments freely that "Any child growing up in Africa is bound to know a thing or two about tyranny ... the coded conversation of parents, the untouchable, preposterous, terrifying figures of absolute authority ... the innocence of childhood against the brutal inanities of strong men in a state gone rotten".

In Osunbade's (2010), the concept of conversational explicature and implicature of Purple Hibiscus and Half of a Yellow Sun are expressly and critically examined and illustrated. Wallis (2002:256) in his paper, examines the relations between language and ideology and zeros in on the Micheal Pecheux's neo-Marxist theory of discourse and his related computerbased method of automatic discourse analysis (analyze automatique du discours' or ADD) Pecheux's other work on Language, Semantics and Ideology was published in 1982. As Anyokwu examines the concept of postmodern gothicism and Olomo discusses the validity of Purple Hibiscus in the Nigerian contemporary societal affair, Osunbade and Wallis discuss the issues of language and ideology in their works. They all, however, did not zero in on the affairs of gender and power and their relational roles cum the motivating factors of the author's use of language and ideological peculiarities.

Makokha, (2014:114) in her book review, examines the problems faced by the African woman in a patriarchal entrenched society. She reacts to result of women being disregarded in the patriarchal African society by the African men and explores the problems faced by the women and the need to negotiate their identity through various forums and platforms and identifies literature as one of them. In the overall, Makokha's paper examines how Adichie, in Half of a Yellow Sun, projects and articulates the place of women characters in the Nigerian society in particular and in the African community at large. Makokha, to a great extent, exhibits the suffering of the African woman in a supposed male-gender ruled world in the text but fails to examine the suffering encountered by the African man from the African woman and her dominance on her gender partners. This study is interested in examining these two ideological preoccupations which Makokha ignored.

The novels of Achebe and Adichie exhibit robust engagements with the issues of linguistic representations, gender and power. These are depicted through various aesthetic elements such as plot-structure, diction, characterisation, settings, themes and others. Nonetheless, their preoccupations with the issues of linguistic representations, gender and power have elicited a myriad of responses from scholars. Thus, this section reviews further some of the extant literature on Achebe's Anthills of the Savannah and There Was a Country ,alongside Adichie's Purple Hibiscus and Half of a Yellow Sun, especially on the discourses of linguistic representations, gender and power.

Kehinde (2008:11) examines how Achebe and Adichie respond, through their novels, to the failed promise of the public sphere in post-colonial Nigeria. Interrogating the issue of power in Achebe's Anthills of the Savannah, the critic notes that public sphere is not made to materialise because of the dictatorship of the ruler. Kehinde contends that "the President of the fictional State of Kangan is intoxicated with power. The President, according to the critic, is apathetic towards dialogue, constructive criticism, egalitarianism and communication. In the novel, Kehinde maintains, "flattery is substituted for real debate and moral force of governing is replaced by the internal struggle over power". Although Kehinde's analysis does not pay much attention to the relationship among linguistic representations, gender and power in Anthills of the Savannah, his observation that flattery is substituted for real debate in the novel 
is insightful. It alludes to the way in which authoritarian rulers deploy the elements of language, especially sycophancy, to sustain their regime. The replacement of debate by flattery is to legitimatise the regime of tyranny and to make the unacceptable acceptable. Likewise, his reference to the President's apathy to dialogue and communication shows the hostility of totalitarian rulers to democratic ethos. It also signifies that military dictatorship is a univocal regime which does not tolerate any dissenting voice. Thus, language is not only a tool of dictatorship, but it is also its victim.

In the same vein, the dimensions of political and gender power are central to Kehinde's interpretation of Adichie's Purple Hibiscus. Kehinde remarks that "although the novel denotatively reads like a mere family saga, it has political overtone". According to him, the novel is about tyranny and people's complicity in their being oppressed; it powerfully evokes Nigerian political landscape. Papa Eugene, Kehinde notes, "displays masculine dominance. He is a replica of an African tyrant "who uses violence to subjugate the ordinary citizens. Kehinde alleges that Mama, Jaja and Kambili are complicit in their oppression by Papa Eugene because of their initial silence about their travails. Okuyade (2009:246) also corroborates Kehinde's claim when he asserts that "in Purple Hibiscus", silence is not only a mechanism or weapon of patriarchal control but domestic servitude. Kambili, Jaja and their Mother devise ways of survival within the utilitarian calculus Eugene has created for their minds. One of the strategies is the domineering silence with which they observe situations...".

However, it is pertinent to note that the silence of Kambili, Jaja and their Mother about their suffering at the hands of their tormentor, Papa Eugene, is also a strategy of resistance. This is because their silence gives Papa Eugene a false sense of authority and being in total control. Also, their initial silence affords them the time and space to plan how to liberate themselves from Papa Eugene's despotism. Their initial refusal to speak about Papa Eugene's tyranny does not signify that they have surrendered to it. Thus, silence is a linguistic strategy of $\mathrm{a} / \mathrm{n}$ (impending) revolt which is dramatised towards the end of the novel.

Similarly, Kehinde's assertion that Kambili and Jaja only communicate with each other through sign language (asusu anya: Igbo words for sign language) because of their fear of Papa Eugene's despotism is valid. Nonetheless, a more careful reading reveals that there is much more to the extra-linguistic technique adopted by Kambili and Jaja to communicate with each other. By resorting to communicating through sign language against Papa Eugene's repressive will, Kambili and Jaja show the ways in which non-conventional linguistic elements are deployed to subvert the regime of tyranny. That Kambili and Jaja interact, through sign language, against Eugene's authoritarianism signifies that the violence by dictatorial rulers, like Papa Eugene, to silence the ordinary people into total submission is illusory. This implies further that resistance can be "verbalised" and performed by the oppressed through various extra-linguistic elements, including silence and sign language. Analysing the issue of gender and power in Anthills of the Savannah from a cultural materialist perspective, Nwagbara (2010:3) asserts that “there is a palpable narrative shift in Achebe's craft in Anthills of the Savannah. The paradigmatic shift in content and style reflects a literary commitment towards addressing the issues posed by women's thralldom in postcolonial Nigeria. He explains further: 'The meat of Achebe's feminist narrative in the novel is to foreground women's subversion of men's ideas and institutionalised practices as well as educating the society about stopping violence meted to women'.

Mhindu (2014:47) underscores Nwagbara's view when she remarks that Anthills of the Savannah is an "exceptional work of art that tries to elevate women" She asserts further that, in the novel, "Beatrice is endowed with brain and beauty that makes her an admirable character for many. Achebe creates a Beatrice who has a first-class Honour degree from Queen Mary College, University of London. Achebe moves the periphery role of women in his earlier novels to playing a central role in shaping and mediating power". However, Mhindu holds as suspect Achebe's feminist engagement in the novel. She declares that: 
There are some elements of feminism that he (Achebe) fails to fully address. For example, Beatrice is well educated with Honours degree and she is the only person with such kind of qualification in her community. To show that men cannot surely be feminists. Achebe makes her secretary, only to take a leading position after Sam, Ikem and Chris' deaths. This may suggest that Achebe is saying that as long as men are there, women cannot occupy those top positions.

However, beyond the residue of "radical" feminism that seems to characterise Mhindu's analysis, Ugwanyi (2011:264) offers a more illuminating insight into Achebe's perception of power and gender in the novel. Writing in respect of Achebe's characterization of Beatrice, Ugwanyi rightly observes that "Beatrice represents the new force that Achebe introduces in the novel. She is the string that ties the three friends together. The three friends find balance in Beatrice. She is there at every time in the novel to act as a cushioning effect to those who grieve and suffer" Ugwanyi's interpretation is quite valid. This is because Achebe does not create the character of Beatrice in order to join the male folks like Sam in the amoral and destructive power struggles that pervade Kangan. Rather, she is created as an "alter-native" figure to signify a path apart from the politics of violence and anarchy. By making Beatrice a "mere" secretary, Achebe means to inform the reader that a positive change is not necessarily a function of individuals in high positions. This point is further underscored by Ugwanyi when he notes that: "She (Beatrice) is the "anthill" that survives that inferno that raged through the whole "Savannah" (State of Kangan). She even performed culture male-designated roles in the novel. Achebe seems to be saying it is high time we changed our attitude towards women in Nigerian society'. Achebe's gender and power affiliation here is more or less well portrayed and well represented by Ugwanyi in this context.

Ugwanyi's perceptive analysis is also corroborated by Bhardway $(2015: 346)$ when he observes that "Achebe, in the novel, does not merely expose the sad state of affair of Nigeria, but he points towards a solution, identifying people with a higher responsibility to mould the society". This implies that Achebe is not concerned about the kind of "gender equality" (or is it struggle?) advocated by some Western radical feminists. Rather, he is concerned about good governance engendered by intra and inter-gendered cooperation and intra and interclass collaboration. Thus, "modernised communalism", rather than radical class or sexist liberation, is the thematic overtone of the novel.

Interrogating the Nigerian-Biafran War and the elites' notion of nationalism in Achebe's There Was a Country, Ekhator (2014:13) contends that "Nigeria's story and Achebe's personal story were told to inspire in future Nigerians the spirit of nationalism, value for where Nigerians are coming from". He notes that "the veritable themes in the memoir are politics of nationhood, ethnic nationalism and national integration" These according to Ekhator, are "the sum of the causes of Nigeria-Biafra War" Writing further on the depiction of power struggle and its implications in the memoir. Ekhator remarks that: "Achebe creates an imaginary scene for traumatic horrors of war. This approach enables the reader to appreciate the themes of the text which appeal to the reader's sense of caution so that such grievous terrorism will be avoided''.

Barnard and Kinggeorge (2014:83) investigate the ways in which the history and memory of Nigeria- Biafra Civil War and its lessons, as depicted in Half of a Yellow Sun and There Was a Country, can engender collective purgation and promote national unity. The critics assert that Half of a Yellow Sun "is not just about loss and destruction, it is also a book of selfdetermination, survival and hope - qualities which Ugwu is endued" They note that Adichie "foreshadows the hope of a new enlightened Nigerian through Ugwu's initial encounter with modernity when he first arrives at Odenigbo's quarters to find spacious rooms wide enough for him to walk around the house up and down touching books, curtains, furniture and plates".

The observation of Barnard and Kinggeorge refers to the transformative power of Western modernity on Ugwu. In spite of the transformative power of Western modernity, 
especially on Ugwu, the novel shows that Western modernity also possesses some destructive elements. The war situation depicted in the novel serves to justify this point. The critics further contend that "the historical fact of ethnicity and race as the bane of Nigeria's unity is projected in the novel though incidents that resonate with the failure of the leadership to identify and harness the positive aspects of Nigeria for national unity". On the representation of the war in the novel, Barnard and Kinggeorge assert that "the war creates an opportunity for unlikely friendship to be forged. Kainene and Olanna rise above their difference and communicate freely". This assertion shows the paradoxical power of war. War, as depicted in the novel, not only destroys people, but it also unites them. In their analysis of There Was a Country, Bernard and Kinggeorge observe that Achebe "has succeeded in preventing our collective memory and history from sinking into atrophy and amnesia, thereby facilitating the process of exorcism." This is one dimension of power of literary art. It boosts national memory and enhances a nation's history.

In her reading of Half of a Yellow Sun, Makokha (2014:112) contends that the novel depicts the myriad of challenges being faced by the African woman in her struggle to carve a niche for herself in post-colonial African society. She argues that the African woman, as portrayed in the novel, suffers double colonization, the first time by the British, and the second time by the Nigerian man in post-colonial Nigeria. While contending that the patriarchy configuration of the postcolonial Nigerian society and, by inference, the African continent marginalises and oppresses educated women, like Olanna, Makokha calls for the urgent need for African men to solve "the problem of patriarchy and domination of women by treating women as their counterpart, and not as second-class citizens, both in the domestic and formal set-up". Despite the fact that Makokha alludes to the conflicts between Mama and Olanna in her analysis, her submission that the already mentally colonised women should decolonise their mindsets tends to suggest that the colonisation of women is exclusively perpetrated by men. The validity of Makokha's analysis is, thus, hampered by its failure to recognise the intragendered colonialism that engenders the suppression of women in the novel. The character of "other woman" like Amala shows that the "African woman" is used as a plural. The manipulation and suppression of Amala by Mama in order to advance her interest in having a grandson signifies that women are also involved in colonising their fellow women. This portends the fact that Adichie does not seem to preach a radical feminist ideological predilection as Makokha's reading portrays here.

Anyokwu (2011:106) focuses on Adichie's deployment of Igbo rhetoric as a narrative strategy in Purple Hibiscus. He asserts that "Adichie follows the pragmatic example of Achebe (...) in constructing Igbo English even as she liberally draws upon the inexhaustible oral resources of the Igbo as the figural "bolts" and "nuts" of her narrative. "The resulting product", contends Anyokwu, "is a literary hybrid shot through with socio-political and epistemic issues". Elaborating further on the use of language in the novel, Anyokwu avers:

The métier of Chimamanda Adichie Ngozi's Purple Hibiscus is the largely adroit interweave of thoroughly domesticated English complete with Nigerianisms, slang, buzzwords, among others. Besides, we find in the novel an admirably successful overlapping of Igbo words, phrase and expressions, which foreground the unique sense of place and contextual realism. Indeed, Adichie's exceptionalism inheres in her deft and surefooted admixture of both the exoglossic and endoglossic codes, i.e, English and Igbo respectively in her work.

From the foregoing explanation, it is evident that Adichie, in Purple Hibiscus, uses the elements of the Igbo language and Nigerian English to subvert the hegemony of the "Master's 
language". Thus, the Igbo words and phrases deployed in the novel are strategies of demonstrating the cultural difference. Cultural difference, through deliberate retention of native language, is a literary technique of giving a voice to postcolonial writers with a view to decentring the hegemony of Western literary traditions. This signifies that language is a tool of power.

Azuike's (2009:86) exploration of Purple Hibiscus and Half of a Yellow Sun focuses on women's struggle to overcome marginalisation and oppression in sexist and patriarchal society. She contends that the "novels are populated by psychopaths, rapists, religious fanatics and ruthless rulers, all of whom terrorise women". Azuike, thus, submits that Adichie uses the novels "as instruments of self-discovery and healing for the abused women in Nigeria who may have undergone traumatic experience". Although Azuike makes a passing reference to Jaja's ordeal in the hands of Papa, her radical feminist interpretations of Purple Hibiscus and Half of a Yellow Sun seem to suggest that women are the only victims of tyranny and other forms of political violence prevalent in contemporary Nigeria. Azuike's radical feminist perspective tends to oversimplify the various dimensions and complexities of power and their abuses depicted in the novels. Apart from the fact that Azuike's reading falls short of realistic representation of Adichie's gender consciousness, her critical judgments, engendered by radical feminist orthodoxies, undermine the novels complex thematic focus. As the novels show, both the female and the male are victims of abuses of power, oppression and human rights violation.

For instance, in Purple Hibiscus, Jaja (a male) is a victim of Papa Eugene's brutality. Ade Coker, an ace (male) journalist and Editor of the Standard newspaper, is assassinated through a parcel bomb by the military junta. Similarly, Papa Nnukwu, an old man, is humiliated and ostracised by his son Papa Eugene. In Half of a Yellow Sun, Mama oppresses Amala, she also insults and humiliates Olanna. Mrs Ozobia conspires with her husband, chief Ozobia, in order to use their daughter, Olonna, as a sex bait to secure a contract from the Minister of Finance, Chief Okonji. Ugwu, a male teenager, is also forced into fighting in the war he knows little or nothing about. All these instances and others show that both the male folk and the female folk are perpetrators and victims of political and domestic violence. Thus, power and its abuses in the novels are not limited to the male as Azuike's analysis seems to suggest. Therefore, Azuike's representation of Adichie as a radical feminist falls sort of the proper position of the author in relation to her feminine gender and power affiliations.

From the foregoing brief review, it is evident that there has been a wealth of writings on Anthills of the Savannah, There Was a Country, Half of a Yellow Sun and Purple Hibiscus. Indeed, the above-mentioned works on the scholars opinion share some similarities with the views of this work in the area of linguistic representations and the investigation of gender and power ideological preoccupations.

There is, however, a somewhat departure from the previous works. It can be noted that most of views of the earlier studies focused on the literary and linguistic features of the texts under study some of which are incongruous and uneven; this is because a lot of the previous reviews offer a somewhat too radical ideological beliefs of the writers which did not in any way represent them well as neither Achebe nor Adichie present or represent blatant or extreme radicalism of gender and power ideological predilections in the selected works for this study. This study attempts to offer a balanced opinion on the literary cum linguistic aspects of gender and power opinions of the scholars, the gender and power literary and linguistic features in the texts and to establish whether the features are ideologically based.

\section{CONCLUSION}

In the foregoing analysis, it is realised that opinion of scholars on gender and power ideological beliefs of Chinua Achebe and Chimamanda Adichie in their selected works are different and multifaceted. It is, therefore, veritable enough to have a comparatively valid view of the conceptual and ideological appraisal of the writers to forge a close and balanced beliefs 
of their works specifically on gender and power discourses. What is missing in the opinions of some of the scholars and the gap our analysis fills in, therefore, is that the ideological beliefs on the issues of gender and power of both Achebe and Adichie are not well positioned by some of the scholars' analysis which our review attempts to put in proper perspective.

\section{REFERENCES}

Achebe, C. (1987). Anthills of the Savannah, London; Heinemann.

-(2012). There Was a Country: a personal history of Biafra; London: Penguin.

Adichie, C.N. (2006). Purple Hibiscus, Lagos: Farafina books.

(2014). Half of a Yellow Sun, Lagos: Farafina books.

Anyokwu, C.( 2009). Postmodern Gothic and Chimamanda Adichie's Purple Hibiscus In Papers In English and Linguistics (PEL) Vol 10. 2009. Ile - Ife, Nigeria: Obafemi Awolowo University Press. 105-125.

Azuike, M.A. (2009). Women's Struggle and Independence in Adichie's Purple Hibiscus and Half of a Yellow Sun African Research Review Vol 3:4 79 - 91.

Bamiro, E.O. (2006). Nativization strategies, Nigerianisms at the intersection of ideology and gender in Achebe's Fiction. In World Englishes. Vol. 25 No 3 - 4 pp. $315-$ 328.

Bernard, C.D \& KInggearge O.P (2014). History Memory and Politics of National Unity in Adichie's Half of a Yellow Sun and Achebe's There Was a Country” International Journal on Studies in English Language And Literature 81 - 89.

Bhardway, P. (2015). The dynamics of change in Africa sensibility: Anthills of the

Savannah In International Journal of Innovative Research and Development Vol. $4: 3345-352$.

Chinweizu , (1990). Anatomy of Female Power: A Masculinist Dissection of Matriarchy. Lagos, Nigeria: Pero Press.

Ekhator, O.G. (2014). “There Was a Country” The Reminiscence of Nigeria - Biafra Civil War and Elites" Perception of Nation and Nationalism. Historical Research Letter Vol. 12. $13-25$. 
Igboanusi, H. (2000). Igbo English in the Nigerian Novel, East Lansing: Michigan State University Press.

Kehinde, A, (2008). Rulers Against Writers, Writers Against Rulers: The failed Promised of the Public Sphere in Postcolonial Nigerian Fiction CODESRIA 1- 31.

Lawal, M.O. (2019) Linguistic Representations of Gender and Power in Selected Works of Chinua Achebe and Chimamanda Adichie. An unpublished Ph.D Thesis submitted to the Faculty of Arts, Department of English, University of Ibadan, Ibadan, Nigeria.

Makokha, G.A. (2014). Portrayal of African Woman in Half of a Yellow Sun In Journal research in Peace, Gender and Development (JRPGD) Vol: 4 (6) pp $111-120$.

Mhindu, A. (2014). Can Men Surely Be Feminist? A Feminist Reading of Ngugi's The River Between and Achebe's Anthills of the Savannah. Research Journal Of English Language and Literature. Vol 2:4 46 - 50.

Nwagbara, U. (2010). Sexist Matters: Power Play and Gender Space in Chinua Achebe's Anthills of the Savannah IRWL Vol 6.11 1-20.

Okuyade, O. ( 2009). Changig Borders and Creating Adichie's Purple Hibiscus. The Journal of Pan African Studies. Vol. 2. 245 - 259.

Olomo, A.( 2011). (Book Review) Purple Hibiscus by Chimamanda Adichie. Posted on December 12, 2011. swans book reviewer.

Onyemelukwe, N.H.( 2011). A Critical Discourse Analysis of Ideology and Meaning in Selected Novels of Chinua Achebe, An unpublished Mphil Thesis Submitted to the Department of English, University of Ibadan, Ibadan, Nigeria.

Osunbade, N. ( 2010). Explicature and Implicature of Conversation in Adichie's Purple Hibiscus and Half of a Yellow Sun. An unpublished Ph.D Thesis, submitted to the Department of English, University of Ibadan, Ibadan, Nigeria.

Proyect, L. (2003). (Book Review) Chinua Achebe's Anthills of the Savannah, Retrieved from the electronic mail on 24th April, 2011. Swans http; www.swan.com

Todd, L. (1982). The English Language in West Africa. In English as a World Language. 
Edited by Richard W. Bailey and Manfrad Gorlarh: Cambridge University Press $281-305$.

Ugwanyi, M.(2011) Achebe's Novels as Historical Documentation of Nigeria in The perspective of Language and Literature : Essays in Honor of R.U.Uzoezie 253271 (n.d).

Walis, M. \& Shepherd S. (2012). Studding Plays, 2ns ed. London: Hodd.er Arnold.

Zabus, C. (1990). The locus - eaters: the Igbo ethno - text. In Chinua Achebe: A Celebration. Edited by Kristen Holst and Anna Rutherford, Oxford: Heinemann pp. $19-30$

\section{AUTHOR'S BIO}

Musibau O. LAWAL earned his Ph.D from the University of Ibadan, Nigeria. He is a lecturer in the Department of English and International Studies, Osun State University, Osogbo, Nigeria. His areas of interest include Stylistics, Ideology, Pragmatics and Discourse Analysis. 